\title{
KAJIAN STRUKTURALISME SEMIOTIK DALAM NOVEL BUMI MANUSIA \\ KARYA PRAMOEDYA ANANTA TOER
}

\author{
Embang Logita
}

\section{Pendidikan Bahasa dan Sastra Indonesia Universitas Wiralodra}

e-mail: embang.logita@unwir.ac.id

\begin{abstract}
ABSTRAK
Tujuan dari penelitian ini untuk mengetahui bagaimana peran semiotika pada sastra dan untuk mengetahui bagaimana hasil dari analisis novel Bumi Manusia melalui pendekatan semiotik.

Penelitian ini menggunakan metode kualitatif. Metode kualitatif adalah prosedur penelitian yang menghasilkan data deskripsi berupa kata-kata terurai dengan jelas dan tidak mengutamakan angka. Data penelitian ini adalah novel Bumi Manusia. Penelitian ini menggunakan pendekatan strukturalisme semiotik untuk mengetahui bagaimana peran semiotika pada sastra dan untuk mengetahui bagaimana hasil dari analisis novel Bumi Manusia melalui pendekatan semiotik.

Pentingnya menganalisis makna dalam sebuah karya sastra menjadi keharusan manakala pembicara ingin memahami secara mendalam keindahan dan unsur etik dalam suatu karya sastra, sehingga beragam pendekatan yang ada merupakan jalan yang tepat digunakan untuk menganalisis sebuah karya sastra. Semiotik adalah salah satu pendekatan yang kerap digunakan dalam menganalisis karya sastra dengan tinjauan dan pemberian makna terhadap beragam tanda yang muncul.
\end{abstract}

\section{Kata Kunci: Bumi Manusia, Strukturalisme Semiotik.}

\section{PENDAHULUAN}

Proses kajian sastra memiliki peran penting dalam kehidupan kebahasaan serta dalam upaya pencarian makna yang lebih dalam tentang sebuah karya sastra. Dalam hal ini dikenal beberapa macam pendekatan sastra. Adapun pendekatan sastra disini adalah teknik yang mengarah pada upaya untuk memperngaruhi emosi dan perasaan pembaca.

Sastra sebagai karya imajinatif yang mempergunakan bahasa memiliki perbedaan dengan karya-karya kebahasaan lainnya yang lebih mementingkan fungsi referensi bahasa berupa penyampaian pesan. Sebaliknya karya sastra mementingkan fungsi estetik bahasa sebagai sarana ekspresinya. Dalam karya sastra pengarang berusaha mendapatkan efek dari penggunaan bahasanya itu, berupa keterkesanan dan keterpesonaan pembaca, disamping diterimanya nilai-nilai tertentu yang biasanya bernilai pendidikan oleh pembaca tanpa disadari. Karya sastra selalu mendapat tanggapan dan pemaknaan yang beraneka ragam dari pembacanya dan tidak selalu tepat dengan pemaknaan yang dimaksud penulis sastra itu sendiri. Hal tersebut dikarenakan perbedaan zaman, pengalaman, kemampuan, pemahaman, dan situasi pembacanya. Dengan kata lain perbedaan pemaknaan tersebut terjadi karena horizon harapan pembaca yang berbeda, sehingga timbul bermacam-macam penafsiran terhadap teks sastra tersebut. 


\section{Dalam kaitannya dengan} pembahasan di atas, Hirsch dalam Djoko Pradopo membedakan arti dan makna. Menurutnya, arti yang diberikan oleh pembaca terhadap teks adalah makna (signifikasi), ia berubah sesuai dengan horizon harapan pembaca teks sastra tersebut. Arti yang diberikan pengarang bersifat tetap dan tidak berubah, disebut arti (meaning).

Tujuan dari penelitian sederhana ini untuk mengetahui bagaimana peran semiotika pada sastra dan untuk mengetahui bagaimana hasil dari analisis novel Bumi Manusia melalui pendekatan semiotik.

\section{KAJIAN TEORI \\ Hakikat Semiotik}

Ilmu yang mempelajari tanda dan makna disebut semiotik atau semiologi. Studi mengenai semiotika mengarahkan dan menuntut kita untuk mengelola simbol yang diterima untuk kemudian bisa digunakan sebagai sarana pemahaman terhadap dirinya sendiri atau penting juga dalam mengukur tindakan berkaitan dengan hidup dan kehidupan sosialnya. Menurut Ferdinand De Sausurre semiology is a science which studies the role of signs as part of social life. Sebagai suatu ilmu yang mempelajari tentang makna tanda, semiotika memiliki cakupan yang sangat luas.

Ilmu yang mempelajari tanda dan makna disebut semiotik atau semiologi. Studi mengenai semiotika mengarahkan dan menuntut kita untuk mengelola simbol yang diterima untuk kemudian bisa digunakan sebagai sarana pemahaman terhadap dirinya sendiri atau penting juga dalam mengukur tindakan berkaitan dengan hidup dan kehidupan sosialnya. Menurut Ferdinand De Sausurre semiology is a science which studies the role of signs as part of social life. Sebagai suatu ilmu yang mempelajari tentang makna tanda, semiotika memiliki cakupan yang sangat luas.

Semiotika dapat dijadikan sebuah pendekatan dalam melakukan analisis karya sastra. Sebuah karya sastra entah puisi, prosa, atau drama menyajikan tanda-tanda yang dibalut dalam makna bahasa yang digunakan. Setiap pembaca dapat mempunyai interpterasi yang berbeda dalam memaknai satu tanda. Namun, semua itu dapat dibatasi oleh adanya pemahaman dalam konvensi bahasa, sastra, dan budaya. Misalnya, bila dalam karya sastra disebutkan tentang lambang atau simbol "bendera kuning", menurut orang Indonesia bermakna ada orang yang meninggal atau "lampu lalu lintas (merah, kuning, hijau) tentu sudah dipahami oleh orang Indonesia.

Bahasa sebagai media dalam memahami karya sastra memiliki peran yang besar dalam memengaruhi pemikiran pembaca. Yang membedakan manusia dengan makhluk lain adalah adanya bahasa. Bahasa mempunyai kekuatan dalam kesosialan lingkungan. Dapat dikatakan bahasa merupakan pranata sosial yang di dalamnya terdapat sistem nilai dalam masyarakat. Begitu kuatnya pengaruh bahasa maka kalangan antropologis mengungkapkan bahwa lambang bahasa menyiratkan adanya komunitas tertentu. Artinya sebuah komunitas akan mempunyai tanda, simbol, lambang bahasa tersendiri dalam komunikasinya baik lisan maupun tulisan. Karena itulah bahasa merupakan hal terpenting dalam kajian atau telaah semiotika.

Banyak definisi dan pengertian yang diberikan para ahli terhadap semiotik, Mansur Pateda menuliskan bahwa semiotik adalah teoeri tentang sistem tanda. Nama lain semitiok adalah semiologi dari bahasa Yunani semeion yang bermakna tanda, mirip dengan istilah semiotik. Alex Sobur menganggap semiotik sebagai suatu model ilmu social yang memahami dunia sebagai sistem hubungan yang memiliki unit dasar yang disebut tanda.

Secara denetatif menurut Paul Cobley dan Litza Janzz (2002:4) semiotic berasal dari kata same, bahasa yunani, yang berarti penafsir tanda. Literature lain menjelaskan bahwa semiotik berasal dari kata semion yang berarti tanda. Dalam 
pengertian yang lebih luas, sebagi teori, semiotic kemudia didefinisikan sebagi studi sistematis tentang produksi dan interperensi, tanda, bagaimana cara tanda-tanda itu bekerja, dan apa manfaatnya terhadap kehidupan.

Pokok perhatian semiotika adalah tanda. Tanda itu sendiri adalah sebagai sesuatu yang memiliki cirri khusus yang penting. Pertama, tanda harus harus dapat diamati dan arti tanda itu harus ditangkapmoleh si pembaca, kedua, tanda harus menunjuk pada sesuatu yang lain, artinya bisa mengantikan, mewakili, atau menyajikan. Tanda dan hubunganhubungannya kunci dari analisis semiotic, dimana relasi tersebut kemudian memumculkan makna atau arti.

Semiotik sebagaimana disimpulkan oleh Burhan adalah ilmu atau metode analisis untuk mengkaji tanda. Tand adalah sesuatu yang mewakili sesuatu yang lain yang dapat berupa pengalaman, pikiran, perasaan, gagasan, dan lain-lain. Perintis awal semiotik adalah Plato (428-348 SM), ia memeriksa asal-muasal bahasa dalam bukunya Cratylus, juga Aristoteles yang mencermati kata benda dalam bukunya Poetics dan On Interpretation. Keterangan tersebut menunjukkan bahwa sejak awal telah disadari bahwa sistem penandaan memiliki pengaruh yang besar, bahkan sejak dulu tanda menjadi sumber perdebatan. Meskipun konsen terhadap sistem tanda-tanda yang ada di sekitar manusia telah ada sejak lama, tetapi dasar penelusuran tentang tanda baru diletakkan pada abad pertengahan dalam ajaran St. Augustinus (345-430 M).

Semiotik sebagai ilmu mempunyai tiga focus area pembelajaran, yaitu, tanda, sistem yang mengaturnya, dan budaya dimana tanda tersebut berada. Tanda merupakan sesuatu yang bersifat fisik, bis dipersepsi oleh indra. Umberto Eco menjelaskan lebih lanjut mengenai tanda bahwa tanda adalah hal yang dapat diambil sebagai penanda yang mempunyai arti penting untuk mengantikan, sesuatu yang lain.

Ada dua hal yang membuat semiotika manarik bagi siapapun yang ingin mempelajarinya lebih lanjut, yang pertama, faktanya adalah terbukti semiotika memiliki kajian aplikastif yang mencakup semua disiplin. Yang kedua, hakikat semiotika sebagi ilmu yang menelaah produksi dan interpretasi tanda membuatnya sudah menarik sejak awal. Hakikat itu tidak lain dari representafif, artinya, realitas selalu melakukan versi seseorang atau sesuatu lembaga mengenai perkara yang tersaji sebagai realitas itu. Pada gilirannya, bisa kita pahami bila semiotika mengatakan bahwa apa yang di anggap realitas bagi orang belum tentu demikian bagi orang lain.

\section{Pemikiran dan Konsep Semiotik}

Disamping tokoh-tokoh yang disebutkan di atas, dalam kajian semiotic tentu kita tidak terlepas dari teori Saurrese. Kajian semiotic adalah pengenalan atas tanda-tanda yang terdapat pada unsur atau bagian dari kebudayaan. Saurrses (1915) menyebutkan bahwa tanda terdiri atas dua muka yang tak terpisahkan, yakni significant dan signifie. Untuk memahami semiotic dalam kebudayaan, Barthes dalam bukunya yang terkenal Mythologies (1957) telah mendefinisikan. Ia bertolak dari teori Saurrses yang melihat semua gejala dalam kebudayaan sebagai tanda yang terjadi atas significant (penanda), yaitu gejala terserap secara mental oleh manusia sebagai "citra akustik", dan signifie (petanda), yaitu makna atau konsep yang di tangkap dari significant tersebut.

Dalam kebudayaan prancis, Barthes mengambarkan pemahaman significant pada signifie-nya sebagai suatu proses dua tahap. Karena significant adalah gejala yang selain diperhatikan oleh kognisi manusia juga diproduksi, maka bila ditinjau dari produksi tanda, significant disebutnya expression (E) (ekspresi, pengungkapan), signifie sebagai content (isi atau konsep). 
Menurut Barthes, hubungan (R) antara $\mathrm{E}$ dan $\mathrm{C}$ terjadi pada manusia dalam lebih dari satu tahap. Tahap pertama adalah dasar (primer) yang terjadi pada saat tada dipahami untuk pertama kalinya, yang kemudian diklasifikasikan dengan $\mathrm{R}_{1}$ antara $\mathrm{E}_{1}$ dan $\mathrm{C}_{1}$. Namun pemaknaan tanda tidak pernah terjadi hanya pada pemaknaan primer. Prosesnya akan berlanjut dengan pengembangannya pada system sekunder yakni $R_{2}$ antara $E_{2}$ dan $C_{2}$. System sekunder adalah lanjutan yang mengmbangkan baik system E ataupun C.

Aliran yang lain dalam semiotic juga dikemukanan Charles Sanders Perirce. Ia beranggapan bahwa jagat raya terdiri atas tanda-tanda. Ini merupakan pandangan pansemiotik tentang jagat raya ini.

Peirce melihat tanda bukan sebuah stuktur, namun berupa suatu oemaknaan "tiga tahap". Model peirce adalah model triadic. Manusia memberi makna pada sebuah tanda melalui sebuah proses pemaknaan tanda yang disebut semiosis. Semiosis merupakan suatu proses "tiga tahap", yakni:

Tahap 1: penserapan representamen (R), yaitu "wajah luar" tanda yang berkaitan dengan manusia secara langsung (ini sering disamakan dengan pengertian tanda)

Tahap 2: perujukan representemenpada objek $\mathrm{O}$, yakni merupakan konsep yang di kenal oleh pemakai tanda berkaitan dengan representemen tersebut.

Tahap3: penafsiran lanjut oleh pemakai tanda, yang disebut interpretan I setelah repserentemen dikaitkan dengan objek.

Sementara teori Peirce mengatakan bahwa sesuatu itu dapat disebut sebagai tanda jika ia mewakili sesuatu yang lain. Sebuah tanda haruslah mengacu/ mewakili sesuatu yang disebut objek. Tanda tersebut harus ditangkap dan dipahami dalam prespektif kesinambungan antara hubungan tanda itu sendiri, ground atau sebuah tanda acuan atau konvensi yang mendasari pemahaman tanda, denotatum yaitu suatu kelas dari acuan yang ditunjuknya. Dan pemahaman makna yang timbul dalam kognisi lewat interpretasi yang disebut interperent.

Peirce membedakan hubungan antara tanda dengan acuannya dalam tiga jenis hubungan yiatu:

1) Ikon, jika ia berupa hubungan kemiripan, foto, peta geografis, penyebutan atau penempatan di bagian awal atau depan (sebagai tanda bahwa sesuatu itu dipentingkan) merupakan contoh dari ikon.

2) Indeks, jika ia berupa hubungan kedekatan eksitensi, misalnya asap hitam sebagi petanda adanya kebakaran, wajah muram sebagai petanda hati yang gundah dan sedih.

3) Simbol, jika ia berupa hubungan yang sudah terbentuk secara konvensi, misalnya morse dari bahasa.

Selanjutnya menurut Eco ketika seseorang menuturkan kata (image) maka ia terlibat dalam sebuah proses produksi tanda, ia memperkerjakan tanda-tanda (memilih, menyeleksi, menata, dan mengkombinaksikan dengan cara dan aturan main tertentu).

\section{Semiotik dalam Sastra}

Kajian semiotik pada satra telah dilakukan sejak mulai diperkenalkan oleh Saussure pada tahun 1920an di eropa dan Peirce serta Moris pada masa yang sama di Amerika. Pada saat itu, kajian semiotika telah mendorong lahirnya berbagai pendekatan dalam kajian sastra, diantaranya pendekatan formalis, pendekatan stuktural dan poststuktural. Diantara berbagai kajian lain, semiotika menduduki tempat yang paling penting pada dewasara ini. Penggunaan konsep-konsep tanda dan makna dalam kajian sastra kian meluas dan dinamis hingga terkadang para pengkajisastra sendiri memanfaatkannya secara semena-mena, tanpa menyatakan bahwa yang ia kerjakan dalam kerangka pemaknaan semiotik tersebut. Menurut 
Aminudin menjelaskan semiotik sastra menjadi:

1) Karya sastra merupakan gejala komunikasi yang berkaitan dengan pengarang, wujud sastra sebagai system tanda, dan pembaca.

2) Karya sastra merupakan salah satu bentuk penggunaan system tanda yang memikili stuktur dalan tata tingkat tertentu.

3) Karya sastra merupakan fakta yang harus di rekontruksi pembaca sejalan dengan dunia pengalaman dan pengetahuan yang dimilikinya.

Adapun beberapa pendapat mengenai kelebihan semiotic dalam menelaah sastra yaitu:

1) Memperindah karya sastra

2) Mengetahui keindahan karya sastra

3) Dalam penelitian analisanya lebih spesifik dan komperhensif

4) Memberikan pemahaman makna dari simbolik baru dalam membaca karya sastra

5) Kita sebagi pembaca semainimal mungkin harus mengtahui dua makna yaitu makna bahasa secara literal dan makna simbolik (global).

Namun ada beberapa kelemahan semiotic dalam menelaah karya sastra yaitu:

1) Kurang memperhatikan stuktur, mengabaikan unsure intrinsic

2) Memerlukan banyak dukungan ilmu batu lain seperti linguistic, sosiologi, psikologi dll.

3) Perlu kematangan konsep luas tentang sastra wawasan luas, dan teorinya.

4) Peranan peneliti sangat penting, ia harus jeli, teliti, dan menguasai materi yang akan diteliti secara totalitas, karena kalau itu tidak dipenuhi maka makna yang ada dalam teks cenderung kurang terekspor untuk diketahui oleh pembaca, justru cenderung menggunakan subjektifitasnya yang menampilkan itu semua dan sangat jarang menggunakan teorinya.
Secara

definitive

tanda adalahsembarangan apa yang mengatakan tentang sesuatu yang lain dari pada dirinya sendiri. Sastra dalam bentuk karya atau naskah juga mengandung makna tanda-tanda non-verbal. Teks sastra pun memiliki cirriciri qualisigns, sinigns, ligsigns. Qualisigns adalah citra, ide, dunis kemungkinan, dan akan menjadi nyata apabila dimasukan kedalam sinsigns. Sinsigns adalah tampilan dalam kenyataan, tanda tak terlembagakan, tanda tanpa kkode. Legisigns adalah tanda yang sudah terlembagakan, tanda atas dasar peraturan yang berlaku umum.

Denotatum karya sastra adalah dunia fiksional, dunia dalam kata-kata, dunia kemungkinan. Tiga sifat denotatum yaitu: ikon, indeks, simbol.

Menurut van Zoest dalam teks sastra diantara ketiga ikon yang paling menarik, ada tiga ikon yaitu ikon tipigrafis, ikon diagramatis, dan ikon metaforis. Teks secara keseluruhan memiliki ciri-ciri indeksikal sebab teks berhubungan dengan dunia yang disajikan. Dikaitkan dengan teks sebagai unsur-unsur karya, dengan indeksikal mikro, juga dibedakan atas tiga macam yaitu:

1) Indeks berkaitan dengan dunia diluar teks

2) Indeks dalam kaitan dengan teks sebagai interkstual

3) Indeks dalam kaitannya dengan teks dalam teks, sebagai interseksual.

Karya sastra memiliki watak otonom dan komunikatif, dengan demikian karya sastra dapat di tinjau dengan pandangan semiotic secara structural (signifikasi) dan komunikatif (ekstrinsik). Secara otonom pengkajian sastra dapat mengunakan pokokpokok pikiran Charles Morris (1971), menurutnya ada 4 macam yang dikaji secara semiotik yaitu:

1) Hubungan antara Lambing

2) Penafsiran lambing

3) Maksud lambing

4) Cara pemakaian lambing.

Seseungguhnya pembaca dalam tataran semiotika akan mengalami penggeseran semiotika dari tanda yang satu 
ke yanda yang lain, karena pembaca berkedudukan sebagi subjek/ objek. Sebagai subjek pembaca adalah pemberi makna atau arti dari sastra itu sendiri dan pembuat amanat dan pemberi nilai terhadap karya sastra yang di telaahnya. Sebaliknya sebagai objek pembaca selalu terkena bermacam pengaruh dan kekuatan social budaya yang melingkupinya.

Novel yang digunakan sebagi objek penelitian adalah novel sastra yang berjudul Bumi Manusia karya Pramudya Anantatoer, seorang sastrawan terkenal di eranya pada saat itu.

\section{METODOLOGI PENELITIAN}

Penelitian ini menggunakan metode kualitatif. Metode kualitatif adalah prosedur penelitian yang menghasilkan data deskripsi berupa kata-kata terurai dengan jelas dan tidak mengutamakan angka. Penulis menggunakan metode deskriptif kualitatif karena metode ini tertuju pada pemecahan masalah dengan jalan mengumpulkan data, menyusun data, menganalisis data, mengklasifikan data dan menginterprestasikannya.

Data penelitian ini adalah novel Bumi Manusia. Penelitian ini menggunakan pendekatan strukturalisme semiotik untuk mengetahui bagaimana peran semiotika pada sastra dan untuk mengetahui bagaimana hasil dari analisis novel Bumi Manusia melalui pendekatan semiotik. Teknik pengumpulan data yang digunakan dalam penelitian ini adalah membaca novel dan analisis dokumen. Validasi data menggunakan trianggulasi data, dan teknik analisis data menggunakan model interaktif.

\section{HASIL DAN PEMBAHASAN}

\section{Analisis Semiotik dalam Novel Bumi Manusia}

Bumi Manusia merupakan salah satu mahakarya dari Pramoedya Ananta Toer yang merupakan novel pertama dalam tetralogi Pulau Buru. Kisah dalam Bumi Manusia berangkat dari abad ke-19 yang pada saat itu masa kolonialisme Belanda masih menjajah di bumi pertiwi. Latar tempat peristiwa banyak terjadi di Pulau Jawa tepatnya di Wonokromo, Surabaya, Jawa Timur. Suasana zaman penjajahan yang menegangkan, mengharu biru, mencekam, dan memprihatinkan melatari penggalan demi penggalan cerita, meskipun ada beberapa penggalan yang menyentuh naluri percintaan.

Cerita dalam Bumi Manusia diawalai dengan perkenalan dari tokoh utama. Seorang laki-laki muda yang penuh semangat, nasionalis, dan berwatak open minded. Minke sebutan untuk tokoh utama itu yang berasal dari golongan bangsawan atau priyayi Jawa. Jiwa pribumi begitu kental dalam dirinya. Meski dibesarkan dalam lingkungan serba ada, ia ternyata tetap menjaga jarak dengan kaum darah biru, terutama orang asing totok.

Sebagai anak pribumi ia berhasil menyenyam bangku pendidikan di sekolah paling bergengsi kala itu, HBS (Hogere Burger School). Upaya itu ia lakukan agar keluar dari kerangka kolonialis yang feodalistis. Apa lacur, tetap saja perlakuan padanya masih diskriminatif. Dirinya yang berasal dari kaum terpandang dan masih bisa mendapatkan sokongan dari pemerintah kolonial, dalam pergaulan tidak demikian. Saat pertama kali ia masuk sekolah elite tersebut, ia harus menanggalkan pakaian keeropaannya dengan balutan tradisi adat Jawa. Yang harus ia kenakan karena sesuai dengan latar belakang asalnya yang notabene seorang pribumi. Selain itu, terlihat jelas dari namanya "Minke" plesetan yang berasal dari "Monkey", itu panggilan diskriminatif dari rekan-rekan kolonialisnya.

Panggilan yang bernada sentimen rasialis itu sebenarnya bukan tanpa maksud dan makna. Tanda atau lambang itu bila dikaitkan dengan tataran bahasa budaya Jawa akan terlihat maksudnya. Di dalam hierarki berkomunikasi budaya Jawa dikenal adanya budaya berbahasa antarkelas. Tatarannya adalah adanya bahasa krama inggil, krama madya, dan ngoko. Dalam bekomunikasi krama inggil diucapkan 
seseorang berderajat sosial lebih rendah kepada lawan bicara yang berstatus sosial lebih tinggi. Namun, lawan bicara yang berderajat sosial tinggi cukup membalas dengan bahasa Jawa ngoko. Dalm hal ini untuk penyebutan "kamu", (bahasa Jawa ngoko-nya "kowe" yang berarti "anak monyet"). Kata monkey, kowe, dan monyet setidaknya menjadi lambang pemisahan antargolongan dalam cerita tersebut. Yaitu adanya jurang antara golongan bangsawan, Indo (campuran pribumi dan asing), totok (asli Eropa), dan rakyat jelata atau pribumi.

Saat bersekolah di HBS dia begitu kagum pada guru bahasa dan sastra Belanda, Magda Peters. Ia adalah seorang perempuan Perancis penganut aliran etis serta sering mengajarkan hakikat kebebasan manusia melalui karya sastra. $B M$ juga diwarnai oleh bumbu kisah percintaan Minke. Tokoh ini bertumbuh menjadi lelaki dewasa setelah memadu kasih dengan Annelies Mellema. Gadis indo terlahir dari rahim seorang nyai bernama Ontosoroh alias Sanikem yang "dijual" oleh bapaknya kepada pembesar pabrik gula Tulangan, Sidoarjo bernama Herman Mellema. Kehadiran Minke di tengah-tengah keluarga Mellema tak disukai Robert, kakak Annelies. Pemuda peranakan Jawa-Belanda itu menunjukkan sikap antipati terhadap segala sesuatu yang berhubungan dengan yang namanya pribumi.

Dalam kisah asmaranya dengan Annelies, ia dipertemukan oleh seorang nyai yang justru ia kagumi karena kegigihan sang nyai. Meski dari kalangan pribumi, Sanikem atau Nyai Ontosoroh adalah satu replika tokoh pribumi yang cerdas dan gigih. Bila ditelaah lebih dalam, sosok nyai ini adalah perlambang pribumi yang tertindas pada masa itu yang ditampilkan dalam sosok seorang perempuan nyai. Sebutan nyai atau gundik disini berarti perempuan simpanan atau yang dinikahi tidak secara sah artinya tidak secara hukum yang pada akhirnya berimbas pada perlakuan hukum formal kolonialis bagi dirinya.
Keluarga Mellema tinggal di sebuah rumah yang dijuluki Boerderij Buitenzorg. Sesungguhnya sebutan ini hanya bagian dari simbol era kolonialisasi. Dalam pengertiannya Boerderij 'istana' Buitenzorg 'bebas masalah atau kesulitan' tak terletak di wilayah Wonokromo, Surabaya, Jawa Timur. Nama itu lebih mengacu pada bangunan megah di pusat kota Bogor, Jawa Barat, sekarang lebih dikenal dengan sebutan Istana Bogor. Kondisi sosiokultur masyarakat Jawa pada abad 19 masih erat menggenggam watak feodal sehingga berakibat timbul sinisme terhadap sosok nyai-nyai, seperti Sanikem. Jangankan masyarakat sekitarnya sudi melihat isi dan proses hidup sang nyai menghadapi perilaku keluarga (terutama suami dan anak laki-laki) sebagai representasi "negara", sinisme masyarakat justru meletakkan posisi Ontosoroh sebagai seorang nyai. Nyai yang sudah disebutkan sebelumnya dianggap wanita rendahan karena dinikahi tidak secara sah. Hanya simpanan kaum bangsawan Indo atau totok.

Sosok Minke sebagai terpelajar meskipun telah berusaha sekuat mungkin menghindari dan melawan sikap pemisahan (segregasi) ras, lingkungan sosial tak pernah beranjak ke arah tatanan masyarakat yang lebih humanis. Terbukti dari hukum positif formal perkawinan versi kolonial menolak perkawinan Minke-Annelies yang dilakukan secara Islam. Sistem pendidikan Eropa di luar kota kelahiran Minke, memang mengakibatkan putusnya kelangsungan tradisi sebuah keluarga dalam kehidupannya. Akan tetapi, itu tidak membuat Minke sepenuhnya memiliki identitas alternatif. Setinggi apapun ia terangkat oleh pendidikannya, ia tetap seorang pribumi, tetap warga negara kelas dua. Perkawinan Minke-Annelies dalam hukum Islam tidak mampu melawan rasialisme antipribumi. Sikap masyarakat kolonial yang rasialis merupakan simbol atas wujud adanya pemicingan terhadap kedaulatan sang pribumi. 
Hal serupa dibuktikan ketika Nyai Ontosoroh dan Annelies dipanggil pihak pengadilan yang melanjutkan gugatan tentang hak waris dan pemeliharaan anak dari pengadilan di Amsterdam. Peristiwa itu diawali dari kedatangan Maurits Mellema, anak sah (dalam versi hukum perkawinan kolonial Belanda) dengan Herman Mellema. Herman Mellema mempunyai anak dan istri di negara asalnya, akan tetapi dia menikah dengan wanita pribumi dan mempunyai anak pula. Dari pengadilan diputuskan bahwa perkawinan Nyai Ontosoroh dengan Herman Mellema tidak sah berikut perkawinan Minke dan Annelis. Pengadilan memutuskan bahwa seluruh harta dan kekayaannya jatuh ke tangan Maurits Mellema. Namun, harta benda di pabrik itu sebenarnya adalah hasil jerih payah Ontosoroh dan Annelies. Herman dan Robert Mellema tak banyak ikut campur. Bapak-anak itu terjebak atau mungkin sengaja menenggelamkan diri dalam rumah pelacuran miring tokoh Tonghoa, Baba Ah Tjong. Sistem pengadilan saat itu tidak memberikan kesempatan pribumi membela diri. Maka Annelis Mellema harus di bawa Maurits ke Belanda. Pada saat itu Annelis jatuh sakit, tetapi hukum yang berlaku telah memaksanya dan memisahkannya dari ibu kandungnya dan suaminya.

Sungguh ironis, orang asli yang sah mempunyai bumi kelahiran tidak bisa berlaku apa-apa. Hukum yang berkuasa memutuskan hubungan ibu dan anak, suami dan istri. Hukum buatan manusia rasis yang semena-mena dan lunturnya kemanusiaan yang menyentuh sampai di dasar hati. Novel bergenre satire ini memaparkan corengmorengnya bumi yang dihuni oleh makhluk bernama manusia. Kiranya kita bisa memetik pelajaran moral dari novel ini .

"Apakah BM seolah menjadi cermin tentang sikap masyarakat dan negara terhadap hukum perkawinan maupun hukum waris seperti saat ini? Rupanya, negara saat itu telah ikut campur dalam urusan perkawinan maupun hak waris. Bukan lagi dalam term antiras pribumi nusantara, tetapi lebih pada upaya politisasi legal formal sebuah perkawinan atau hak waris."

Selanjutnya dalam menganalisa unsure semiotic dalam suatu karya sastra, maka perlu juga adanya penafsiran dari setiap kata atau dikenal denganistilah heuristic, atau disebut dengan semiotic tingkat pertama, dan juga penafsiran secara totalitas yakni dikenal dengan istilah hermeunitik, atau disebut juga dengan istilah semiotic tingkat kedua, adapun contoh pengenalan kedua unsure semiotic tersebut adalah sebagai berikut:

\section{Secara heuristic}

1. Nyai

Secara heuristic (semiotik tingkat pertama) kata "Nyai" sudah dapat diinterpretasikan sebagai simbol ketercelaan atau hinaan dalam masyarakat jawa yang diletakan pada perempuan simpanan, atau mereka yang dijadikan gundik atau istri simpanan para penjajah, atau mereka yang dijadikan gundik kaum priyayi atau oleh petinggi VOC. Tanda atau simbol tersebut hidup dimasyarakat jawa pada zaman kolonial.

\section{Rumah border}

Kata Rumah border sudah dapat dipastikan itu bukan arti sebenarnya melainkan simbol dari suatu makna yang terdapat didalamnya yakni suatu tempat yang penuh dengan dunia kegelapanatau dunia maksiat, wanita yang ada di dalam tempat itu sudah pasti wanita yang tidak baik dan simbol tersebut sudah melekat di masyarakat sejak zaman kolonial karena pada zaman itu lah rumah border menjadi lebih terkenal karena para penjajah sangat senang berada di temapt itu 3. Priayi

Kata Priayi sudah dapat diartikan adalah symbol dari kekuatan, kehormatan, derajat dari seseorang yang mempunyai segala hal, kata priayi merupakan kata atau panggilan terhadap masyarakat pribumi khususnya jawa yang mempunyai kededukan tinggi.

\section{Menir}

Kata menir merupakan symbol bagi orang belanda yang sedang menjajah Indonesia, dimena mereka di sebut menir oleh rakyat 
pribumi dan sebutan itu hanya untuk bangsa penjajah saja.

5. Minke

"Minke" plesetan yang berasal dari "Monkey", itu panggilan diskriminatif dari rekan-rekan kolonialisnya. Panggilan yang bernada sentimen rasialis itu sebenarnya bukan tanpa maksud dan makna. Tanda atau lambang itu bila dikaitkan dengan tataran bahasa budaya Jawa akan terlihat maksudnya.

6. Kamu

Kata "kamu", sudah dapat diinterpretasikan sebagai simbol ketercelaan atau hinaan dalam bahasa Jawa ngoko-nya "kowe" yang berarti "anak monyet". Kata monkey, kowe, dan monyet setidaknya menjadi lambang pemisahan antargolongan dalam cerita tersebut. Yaitu adanya jurang antara golongan bangsawan, Indo (campuran pribumi dan asing), totok (asli Eropa), dan rakyat jelata atau pribumi.

7. Boerderij Buitenzorg

Sesungguhnya sebutan ini hanya bagian dari simbol era kolonialisasi. Dalam pengertiannya Boerderij 'istana' Buitenzorg 'bebas masalah atau kesulitan'.

\section{Secara hermeunitik}

\section{Nyai}

Secara hermeunitik (semiotik tingkat kedua) kita dapat menafsirkan keberadaan "nyai" tersebut menunjukan tanda kehidupan perempuan pribumi yang dipandang rendah oleh bangsawan kolonial, sehingga tahapan pemaknaan secara totalitas melekat pada Nyai Ontosoroh sebaga perempuan pribumi yang menjadi gundik pada masa colonial. Nyai Ontosoroh merupakan mertua Minke, tokoh utama dalam Roman Bumi Manusia.

2. Rumah border

Kita dafat menafsirkan kata rumah border dapat menunjukan tanda kehidupan yang sangat suram dimana perempuan pribumi di perjual belikan kepada para penjajah mereka dipajang layaknya pakaian yang akan di jual.

\section{Priayi}

Kita dafat menafsirkan bahwa kata priayi dapat menunjujan kekuasaan pribumi khususnya orang jawa, kata ini mulai dikenal pada masa kolonial bahkan samapai sekarang penggunaan kata itu masih dipakai di daerah-daerah tertentu di Jawa.

4. Menir

Kata menir dapat dipastikan bahwa menir menunjukan panggilan bagi para penjajah oleh raykat pribumi.

5. Minke

Panggilan "Minke" mempunyai makna tersendiri yang apabila ditellah lebih jauh arti kata minke merupakan plesetan yang berasal dari "Monkey", itu panggilan diskriminatif dari rekan-rekan kolonialisnya. Dan panggilan itupun merupakan panggilan ledekn atau cemoohan dari kaum colonials di sekolahnya.

6. Kamu

Kata "kamu", kita dapat menafsirkan keberadaan "kowe" tersebut menunjukan tanda kehidupan kaum pribumi yang dipandang rendah oleh bangsawan colonial, sehingga tahapan pemaknaan secara totalitas melekat pada sudah dapat menjadi lambang pemisahan antargolongan dalam cerita tersebut. Yaitu adanya jurang antara golongan bangsawan, Indo (campuran pribumi dan asing), totok (asli Eropa), dan rakyat jelata atau pribumi.

\section{Boerderij Buitenzorg}

Sesungguhnya sebutan ini hanya bagian dari simbol era kolonialisasi. Dalam pengertiannya Boerderij 'istana' Buitenzorg 'bebas masalah atau kesulitan'.

\section{Ketidaklangsungan Ekspresi dalam Novel Bumi Manusia}

Dalam kajian semiotik novel Bumi Manusia banyak terdapat ungkapanungkapan yang secara tidak langsung dinyatakan. Ungkapan-ungkapan tersebut merupakan suatu system tanda yang menunjukan system budaya pada saat itu. Sehingga, beragam kata yang ditemukan dalam novel tersebut merupakan ke khasan bahasa Pramoedya dan juga suatu model 
ungkapan yang memunculkan banyak makna, dengan demikian semakin banyak jenis dimana posisi semiotic memiliki peranan penting dalam menginterperesikan tanda-tanda atau ungkapan-ungkapan yang dinyatakan secara tidak langsung, bahkan melaluui simbol-simbol kehidupan sekaligus.

Disamping itu, jelas juga tergambarkan model pengungkapan yang secara tidak langsung mencirikan karakter perbedaan atau status budaya dalam tafsiran Pramoedya, antara lain sebagai berikut:

1. Pada jam lima sore Surabaya telah ada di bawah roda kereta.

Tahapan proses pemaknaan semiotiknya adalah: telah ada bawah roda kereta (representemen), yang menjelaskan tempat (Objek) yaitu Surabaya. Sehingga analisis semiotik menunjukan bahwa akan keberadaan kereta di suatu tempat atau daerah.

2. Produk jawa yang dibesarkan eropa

Seorang Minke yang merupakan keturunan Kawa di gambarkan oleh Pramoedya sebagai pribumi yang berilmu dan berpengetahuan tinggi tentang eropa, dimana pada akhirnya dialah yang dihadapkan pada dua sisi bandingan atau buruk budaya Jawa dan Eropa. Ini dapat dilihat pada:

"ilmu dan pengetahuan, yang kudapatkan dari sekolah dan kusaksikan sendiri pernyataan dalam hidup, telah membikin pribadiku menjadi agak berbeda dari sebangsaku pada umumnya. Menyalahi wujudku sebagai orang Jawa atau tukdak aku pun tidak tahu" (hal 2)

Juga pada:

"jelas aku keturunan sastria jawa maka sendiri seorang satria jawa pula. Hanya mengapa justru bukan orang jawa yang membikin aku menjadi begini gagah? Dan ganteng? Mengapa orang Eropa?..." (hal. 128)

Hal yang sama juga terjadi pada Nyai Ontosoroh yang dalam hal ini adalah seorang pribumi namun karena menjadi gundik Herman Mallema, maka secara tidak langsung budaya Eropa tertanam dalam dirinya, terlihat ketika dia membiarkan putinya tidur sekamar dengan lelaki yang bukan suaminya yaitu Minke meski budaya Jawa hal ini tidak dipernenankan.

3. "Malu" hanya milik orang jawa dengan segala kerendahannya

"jangan sekali-kali bicara soal malu tentang eropa. Mereka hanya tahu mencapai maksud-maksudnya. Jangan kau lupa, Nak Nyo" (hal 330)

Pengalaman tersebut menunjukan bagaimana eropa yang tidak pernah tahu malu, berbeda dengan orang Jawa yang selalu memegang teguh kehormatan meski untuk melindungi kehormatannya itu mereka selalu merendah, pasrah dan tak jarang malatah. Ini karena rasa malu yang dimiliki orang jawa, takutnya seandaninya pandangan orang lain atas dirinya jatuh.

4. Ilmu pengetahuan dan hokum Eropa yang buta

"ilmu pengetahuan semkin banyak melahirkan keajaiban. Dongengnya leluhur sampai pada malu tersipu. Tak perlu lagi orang betapa bertahun untuk dapat berbicara dengan seseorang diseberang lautan.. (hal. 316)

Ilmu pengetahuan sebenarnya yang membuat eropa begitu kuat dan berkuasa, sedang orang jawa yang selamanya selalu hanya menunggu hasil cipta bangsa Eropa masih terlihat kebudak-budakan seperti dibawah ini:

"Minke kalau kau bersikap begitu terus, artinya mengambil sikap eropa, tidak kebudak-budakan seperti orang jawa seumumnya, mungkin kelak kau bisa jadi orang penting.." (hal. 143)

Sedangkan untuk hukum ysng mengatur dan mengikat, seakan tidak ada nurani dalam hukum itu sendiri. Apa yang telah diputuskan maka itulah yang harus dijalankan.

"dengan akan dilaksanakan perampasan terhadap istriku daripadaku sesuai dengan keputusan pengadilan, bertanyalah aku pandai nurani Eropa: 
adakah perbudakan terkutuk ini akan dihidupkan kembali.."(hal 336)

Sampai pada akhirnya Minke harus kehilangan seornag istri yang telah dinikahinya secara syah dan kalah pada keputusan pengadilan yang mencoba menginventariskan masnusia.

Dari beberapa uraian diatas tergambar jelas gaimana seorang Minke dalam menghadapi dua budaya sesungguhnya dia lebih menerima cara pandang eropa yang terbuka untuk maju dari pada cara pandang jawa yang selalu merendah, sedangkan unutk hukum, dia lebih menereima hukum jawa yang didasarkan pada etika dan nilai kemanusian dapripada hukum Eropa yang buta. Semua bahasa atau ungkapan-ungkapan diatas yang dimunculkan menunjukan polemic tanda kehidupan yang serat dilematis.

Unsur-unsur ketidaklangsungan ekspresi dalam Roman tersebut menjadi cirri penulisan dalam menawarkan makna kehidupan melalui tanda-tanda budaya yang melekat pada saat itu, sehingga kekhasan pengungkapan menjadi milik sepenuhnya pengarang dan pembaca juga merupakan subyek utuh dalam menafsirkan makna dan tanda dengan senantiasa memahami latar belakang seta alur lehidupan pada masa itu. Jadi, ketidaklangsungan ekpresi akan turut dipahami pembaca melalui kedalaman berpikir dan memperhatikan pengaruhpengaruh ekpresi secara menyeluruh.

\section{SIMPULAN}

Karya sastra adalah cerminan kehidupan sosial. Ia merupakan kristalisasi nilai dan pengalaman hidup. Sastra menampilkan gambaran kehidupan dan kehidupan adalah kenyataan budaya, kehidupan mencakup hubungan antara manusia, hubungan antara masyarakat, dan antara masyarakat yang terjadi dalam batin manusia, paparan tersebut menunjukan bahwa karya sastra tidak berangkat dari ketiadaan budaya. Kode budaya dalam sastra memberi pengertian bahwa karya sastra merupakan wujud hasil budaya yang di dalamnya jelas terepresantikan nilai-nilai nudaya masyarakat. Seperti yang ditunjukan Pramoedya anantatoer dalam novel bumi manusia ini, budaya barat yang berkembang dengan cepat dihadapkan pada budaya timur khususnya budaya Jawa.

Pentingnya menganalisis makna dalam sebuah karya sastra menjadi keharusan manakala pembicara ingin memahami secara mendalam keindahan dan unsur etik dalam suatu karya sastra, sehingga beragam pendekatan yang ada merupakan jalan yang tepat digunakan untuk menganalisis sebuah karya sastra. Semiotik adalah salah satu pendekatan yang kerap digunakan dalam menganalisis karya sastra dengan tinjauan dan pemberian makna terhadap beragam tanda yang muncul.

\section{DAFTAR PUSTAKA}

Toer, Pramoedya, Ananta. 2006. Bumi Manusia. Jakarta: Lentera Dipantara.

Zamzamah, Sarjinah. 2000. "Bumi Manusia". (online) Dalam http://id.shvoong.com/books/n ovel-novella/1720037-bumimanusia-/

(Diakses pada tanggal 02 Juni 2018).

Rohim. 20019. "Strukturalisme Semiotik". (online) Dalam https://jabrohim.wordpress.co $\underline{\mathrm{m} / 2009 / 02 / 28 / \text { strukturalisme- }}$ semiotik/.

(Diakses pada tanggal 02 Juni 2018). 